\title{
Suppressors of Cytokine Signaling in Sickness and in Health of Pancreatic $\beta$-Cells
}

\author{
Cheng Ye and John P. Driver* \\ Department of Animal Sciences, University of Florida, Gainesville, FL, USA
}

Suppressors of cytokine signaling (SOCS) are a family of eight proteins that negatively regulate Janus kinase and signal transducers and activators of transcription signaling in cells that utilize this pathway to respond to extracellular stimuli. SOCS are best known for attenuating cytokine signaling in the immune system. However, they are also expressed in many other cell types, including pancreatic $\beta$-cells, where there is considerable interest in harnessing SOCS molecules to prevent cytokine-mediated apoptosis during diabetes and allogeneic transplantation. Apart from their potential as therapeutic targets, socS molecules play a central role for regulating important functions in $\beta$-cells, including growth, glucose sensing, and insulin secretion. This review will discuss SOCS proteins as central regulators for diverse cellular processes important for normal $\beta$-cell function as well as their protective anti-apoptotic effects during $\beta$-cell stress.

\section{OPEN ACCESS}

Edited by:

Masaaki Murakami,

Hokkaido University, Japan

Reviewed by: Akihiko Yoshimura, Keio University, Japan

Takayuki Yoshimoto,

Tokyo Medical University, Japan

*Correspondence: John P. Driver jdriver@ufl.edu

Specialty section:

This article was submitted to Inflammation,

a section of the journal

Frontiers in Immunology

Received: 18 February 2016

Accepted: 18 April 2016

Published: 09 May 2016

Citation:

Ye C and Driver JP (2016)

Suppressors of Cytokine Signaling in Sickness and in Health of Pancreatic $\beta$-Cells.

Front. Immunol. 7:169. doi: 10.3389/fimmu.2016.00169
Keywords: suppressors of cytokine signaling, $\beta$-cells, SOCS expression, insulin signaling, inflammatory cytokines, diabetes, $\beta$-cell growth

\section{INTRODUCTION}

$\beta$-cells within the islets of Langerhans secrete the hormone insulin, not only in response to glucose but also in response to other nutrients, hormones, and neuronal stimuli (1). The primary role of $\beta$-cells is to maintain plasma glucose levels within tight physiological ranges for optimal functioning of the body's cells. Normal physiology places high demands on $\beta$-cells compared to non-secretory cells, which may contribute to pathological conditions associated with pancreatic islet destruction and dysfunction, including types 1 and 2 diabetes. Type 1 diabetes develops from the autoimmune destruction of $\beta$-cells, while type 2 diabetes results from insulin resistance that ultimately causes $\beta$-cell exhaustion. Although the etiology of each disease is different, both disorders involve $\beta$-cell dysregulation through cytokine-induced inflammation $(2,3)$.

The capacity of $\beta$-cells to respond to their environment and dynamically adjusts blood glucose levels depend on multiple receptors and biological signaling pathways that interactively mediate glucose sensing and insulin secretion. Many of these pathways initiate signal transduction by activating the Janus kinase and signal transducers and activators of transcription (JAK-STAT) pathway (4). It is now established that JAK-STAT signaling is inhibited by a family of intracellular proteins collectively known as suppressors of cytokine signaling (SOCS) that reduce the magnitude and/or duration of signals induced by diverse receptors (5-8). Although originally known for inhibiting cytokine signaling in immune cells through a classical negative feedback loop, SOCS proteins emerged as important modulators of additional pathways, including those that control insulin secretion and $\beta$-cell development and proliferation. Eight members of the SOCS family have been described, including SOCS1-7 and CIS. SOCS molecules have in common that they contain a central Src-homology 2 (SH2) 
domain, a conserved $\mathrm{COOH}$-terminal SOCS box, and a variable N-terminal domain $(9,10)$. Two SOCS molecules, SOCS-1 and SOCS-3, contain a kinase inhibitory region (KIR) $(11,12)$. SOCS proteins inactivate JAK-STAT signaling by binding directly to the tyrosine-phosphorylated residues on JAKs via the $\mathrm{SH} 2$ domain that blocks access of STATs to receptor-binding sites. They also suppress signaling by directly inhibiting JAK kinase activity and by targeting receptors and JAKs for degradation by the proteasome [reviewed in Ref. $(13,14)]$. Here, we focus on what is known about the expression of SOCS proteins in $\beta$-cells and how SOCS molecules regulate $\beta$-cell function under normal and pathophysiological conditions.

\section{SOCS EXPRESSION IN $\beta$-CELLS}

In general, Socs genes are expressed at low or undetectable levels in resting cells but become rapidly induced after stimulation with cytokines or hormones. Their transcription is upregulated by the STAT and NFkB-transcription factors, and the resultant SOCS proteins generated subsequently suppresses the same pathway that stimulated their production. Table 1 describes what is currently known about the expression of different SOCS family members in $\beta$-cells. In primary human and mouse $\beta$-cells, SOCS-1, -2 , and CIS are expressed at low baseline levels, although SOCS-3 message and protein are virtually undetectable in unmanipulated healthy islets. Interestingly, expression of SOCS-1, -2, and -3 proteins is upregulated in islet cells from human type 1 diabetes (T1D) patients compared to healthy controls (15). Also, islets purified from NOD mice that develop spontaneous T1D express increased levels of SOCS during the progression of pancreatic insulitis, including CIS and SOCS-2 transcripts from 7 weeks of age and SOCS- 1 transcripts from 10 weeks of age (16). These findings suggest that $\beta$-cells synthesize SOCS proteins in response to the pro-inflammatory environment that accompanies $\beta$-cell autoimmunity.

Several studies have investigated which specific cytokines induce SOCS expression in $\beta$-cells. These have revealed that some cytokines induce the expression of several Socs genes, while others induce only one or a few. Chong et al. demonstrated that interferon $\gamma$ (IFN $\gamma$ ) induces prolonged SOCS-1 mRNA expression $(>48 \mathrm{~h})$ in NIT-1 cells, a NOD mouse-derived insulinoma cell line, which peaks $4 \mathrm{~h}$ after cells are cultured with the cytokine. They also found that IFN $\alpha$ stimulates NIT- 1 cells to transiently express SOCS- 1 that peaks $2 \mathrm{~h}$ after stimulation and then rapidly decays (16). Primary mouse islets separately treated with IFN $\gamma$, but not IL- $1 \beta$ or TNF $\alpha$, upregulated SOCS- 1 expression. In the same study, SOCS-2 and CIS expression were rapidly induced in NIT- 1 cells and mouse islets, incubated separately with IFN $\gamma$, IL- $1 \beta$, or TNF $\alpha$. However, IFN $\alpha$ did not increase CIS and SOCS-2 transcripts above baseline levels (16).

Interleukin-1 $\beta$ rapidly stimulated SOCS-3 transcription in the RINm5F rat $\beta$-cell line that spiked $2 \mathrm{~h}$ after incubation (17, 18). SOCS-3 mRNA is also induced in primary human $\beta$-cells exposed to IL-1 $\beta$, although the effect on SOCS-3 expression was greater when IL- $1 \beta$ was combined with $\operatorname{IFN} \gamma$ and $\operatorname{TNF} \alpha(19,20)$ In rat islets, IL- $1 \beta$ stimulated a 20 -fold increase in SOCS- 3 mRNA after $4 \mathrm{~h}$ of culture that returned to baseline levels within $24 \mathrm{~h}$
$(19,21)$. IFN $\gamma$ also upregulated SOCS-3 transcription; however, the increase in expression was transient compared to IL-1 $\beta$ and the effect disappeared within $24 \mathrm{~h}$ after stimulation. The combination of IL- $1 \beta$ and IFN $\gamma$ additively increased SOCS- 3 mRNA levels in rat islets. By contrast, Lv et al. found that combined IL- $1 \beta$ and IFN $\gamma$ treatment actually downregulated SOCS-3 protein expression in the RIN rat $\beta$-cell line and in primary rat islets after 1 and $24 \mathrm{~h}$ of incubation, respectively (22).

Suppressors of cytokine signaling proteins are also expressed in response to hormones that alter energy metabolism to accommodate different physiological conditions. Pregnancy induced high levels of CIS and SOCS- 2 transcription in mice when $\beta$-cell proliferation was stimulated by lactogens $(23,24)$. SOCS- 3 transcription is also induced when rat and human $\beta$-cells are treated with leptin, a satiety hormone $(19,20,25)$. Another study showed that resistin, an adipokine that contributes to insulin resistance, induces SOCS-3 protein expression in primary mouse $\beta$-cells (26). It is important to note that multiple post-transcriptional mechanisms are used to regulate the levels of some SOCS proteins (27). Therefore, measuring mRNA transcription alone may not adequately describe SOCS expression in $\beta$-cells.

\section{EFFECTS OF SOCS ON INSULIN PRODUCTION AND SIGNALING}

Suppressors of cytokine signaling proteins appear to "finetune" insulin synthesis and secretion by $\beta$-cells in response to a variety of external stimuli. Some of these are hormones that stimulate or suppress insulin production for regulating normal energy metabolism, while others are cytokines that alter insulin signaling during inflammatory conditions. Although changes in SOCS expression undeniably affects insulin signaling in $\beta$-cells, disagreements between the model systems used to investigate this phenomenon has made it difficult to firmly establish the natural contribution of SOCS to pancreatic islet function. Some of these discrepancies are highlighted below.

Suppressors of cytokine signaling regulation of GH-stimulated insulin secretion was explored by Rønn and colleagues (28) because it was known that GH stimulates insulin production by $\beta$-cells $(29,30)$ and because SOCS molecules inhibit GH signaling in other tissues (31-33). It was found that SOCS-3 inhibits $\mathrm{GH}$-induced insulin mRNA transcription in a RIN-5AH $\beta$-cell line that was transfected with an inducible SOCS-3 expression system. SOCS-3 overexpression abolished STAT3 and STAT5 activation and DNA-binding ability. The JAK2-STAT5 pathway is the main signaling pathway triggered by $\mathrm{GH}$ in $\beta$-cells where STAT5 molecules are known to translocate to STAT5-specific elements of the insulin promoter $(29,34-36)$. Thus, the authors postulated that SOCS-3 blocks $\mathrm{GH}$-induced insulin production by reducing the amount of activated STAT 5 available for stimulating insulin expression. These conclusions contrast with a more recent study by the same authors, which found that female mice with $\beta$-cell-specific overexpression of SOCS-3 actually exhibit enhanced glucose tolerance compared to littermate controls, in spite of developing smaller islets (37). It was postulated that SOCS-3 mediates inhibition of several different signaling 
TABLE 1 | Expression of SOCS family members in $\beta$-cells.

\begin{tabular}{|c|c|c|c|c|c|}
\hline $\begin{array}{l}\text { socs family } \\
\text { members }\end{array}$ & $\beta$-cell source & Stimulation conditions & $\begin{array}{l}\text { Product } \\
\text { measured }\end{array}$ & Expression & Reference \\
\hline \multirow[t]{14}{*}{ SOCS-1 } & \multirow[t]{4}{*}{ Human islet cells } & Baseline; 10 healthy subjects & mRNA & Constitutively expressed at low levels & \multirow[t]{4}{*}{$(15)$} \\
\hline & & $\mathrm{IFN} \gamma+\mathrm{IL}-1 \beta+\mathrm{TNF} \alpha$ & mRNA & Markedly increased compared to baseline & \\
\hline & & Baseline; 10 healthy subjects & Protein & Detected at low levels & \\
\hline & & Baseline; 3 T1D patients & Protein & High compared to healthy controls & \\
\hline & \multirow[t]{5}{*}{ Mouse islet cells } & Baseline (NOD.SCID) & mRNA & Constitutively expressed at low levels & \multirow[t]{5}{*}{$(16)$} \\
\hline & & IL-1 $\beta$ (NOD.SCID) & mRNA & None detected & \\
\hline & & TNF $\alpha$ (NOD.SCID) & mRNA & None detected & \\
\hline & & IFN $\gamma(N O D . S C I D)$ & mRNA & Peak at 4 h post incubation & \\
\hline & & Baseline (NOD) & mRNA & Detected by 70 days of age & \\
\hline & & $\mathrm{IL}-1 \beta$ & mRNA & Does not induce unless combined with IFN $\gamma$ & \multirow[t]{5}{*}{$(16)$} \\
\hline & \multirow{4}{*}{$\beta$-cell line } & $\mathrm{TNF} \alpha$ & mRNA & Does not induce unless combined with IFN $\gamma$ & \\
\hline & & $\mathrm{IFN} \alpha$ & mRNA & Peak at $2 \mathrm{~h}$ post incubation & \\
\hline & & $\mathrm{IFN} \gamma$ & mRNA & Peak at $4 \mathrm{~h}$ post incubation and remains elevated & \\
\hline & & $\mathrm{IFN} \gamma$ & Protein & Increased after $4 \mathrm{~h}$ and remains elevated beyond $24 \mathrm{~h}$ & \\
\hline \multirow[t]{15}{*}{ SOCS-2 } & \multirow[t]{4}{*}{ Human islet cells } & Baseline; 10 healthy subjects & mRNA & Constitutively expressed at low levels & \multirow[t]{4}{*}{$(15,56)$} \\
\hline & & $\mathrm{IFN} \gamma+\mathrm{IL}-1 \beta+\mathrm{TNF} \alpha$ & mRNA & Markedly increased compared to baseline & \\
\hline & & Baseline; 10 healthy subjects & Protein & Detected at low levels & \\
\hline & & Baseline; 3 T1D patients & Protein & High compared to healthy controls & \\
\hline & \multirow[t]{7}{*}{ Mouse islet cells } & Baseline (NOD.SCID) & mRNA & Low & \multirow[t]{6}{*}{$(16,57)$} \\
\hline & & Baseline (C57BL/6J) & Protein & Very low & \\
\hline & & IL-1 $\beta$ (NOD.SCID) & mRNA & Peak at $4 \mathrm{~h}$ post incubation & \\
\hline & & TNF $\alpha$ (NOD.SCID) & mRNA & Peak at $1 \mathrm{~h}$ post incubation & \\
\hline & & IFN $\gamma(\mathrm{NOD} . \mathrm{SCID})$ & mRNA & Peak at $1 \mathrm{~h}$ post incubation & \\
\hline & & Baseline (NOD) & mRNA & Detected by 50 days of age & \\
\hline & & Pregnancy (C57BL/6J, CD-1) & mRNA & Increased by day 14.5 of pregnancy & (24) \\
\hline & NIT-1 mouse & $\mathrm{IL}-1 \beta$ & mRNA & Peak at $1 \mathrm{~h}$ post incubation & \multirow[t]{4}{*}{$(16)$} \\
\hline & \multirow[t]{3}{*}{$\beta$-cell line } & $\mathrm{TNF} \alpha$ & mRNA & Peak at $1 \mathrm{~h}$ post incubation & \\
\hline & & $\mathrm{IFN} \alpha$ & mRNA & Not changed compared to baseline & \\
\hline & & $\mathrm{IFN} \gamma$ & mRNA & Peak expression at $1 \mathrm{~h}$ post incubation & \\
\hline \multirow[t]{16}{*}{ SOCS-3 } & \multirow[t]{6}{*}{ Human islet cells } & Baseline; 10 healthy subjects & mRNA & Constitutively expressed at low levels & \multirow[t]{2}{*}{$(15)$} \\
\hline & & $\mathrm{IFN} \gamma+\mathrm{IL}-1 \beta+\mathrm{TNF} \alpha$ & mRNA & $\begin{array}{l}\text { Sixfold increase at } 4-6 \mathrm{~h} \text { post incubation, remains elevated } \\
\text { beyond } 24 \mathrm{~h}\end{array}$ & \\
\hline & & $\mathrm{IL}-1$ & mRNA & $\begin{array}{l}\text { Fourfold increase at } 4 \mathrm{~h} \text { post incubation, decays to baseline } \\
\text { levels within } 24 \mathrm{~h}\end{array}$ & $(15,19)$ \\
\hline & & Baseline; 10 healthy subjects & Protein & Detected at low levels & \\
\hline & & Baseline; 3 T1D patients & Protein & High compared to healthy controls & $(15)$ \\
\hline & & Leptin & mRNA & Strong induction after $12 \mathrm{~h}$ & (20) \\
\hline & \multirow[t]{5}{*}{ Rat islet cells } & Baseline & mRNA & Low & $(19,21,28)$ \\
\hline & & $\mathrm{IFN} \gamma$ & mRNA & Not different compared to baseline & (19) \\
\hline & & $\mathrm{IFN} \gamma$ & mRNA & Markedly increased compared to baseline & $(21,28)$ \\
\hline & & $\mathrm{IL}-1 \beta+\mathrm{IFN} \gamma$ & mRNA & $\begin{array}{l}20 \text {-fold increase at } 4 \mathrm{~h} \text { post incubation and decays to } \\
\text { baseline levels within } 24 \mathrm{~h}\end{array}$ & (19) \\
\hline & & $\mathrm{IL}-1 \beta+\mathrm{IFN} \gamma$ & Protein & Below baseline & $(22)$ \\
\hline & RIN rat $\beta$-cell line & $\mathrm{IL}-1 \beta$ & mRNA & 4.3-fold increase at $2 \mathrm{~h}$ post incubation & $(17,18,20)$ \\
\hline & & $\mathrm{IL}-1 \beta+\mathrm{IFN} \gamma$ & Protein & Below baseline & (22) \\
\hline & INS-1 rat cell line & Leptin & mRNA & Increased by 30 min post incubation & (20) \\
\hline & Mouse islet cells & Leptin $(o b / o b)$ & mRNA & Peak at $6 \mathrm{~h}$ post incubation (in vivo treatment) & (20) \\
\hline & & Resistin (ICR) & Protein & Increased expression by $12 \mathrm{~h}$ & (26) \\
\hline CIS & Mouse islet cells & Baseline (NOD.SCID) & mRNA & Constitutively expressed & $(16)$ \\
\hline & & IL-1 $\beta$ (NOD.SCID) & mRNA & Increased within $1 \mathrm{~h}$ post incubation & \\
\hline & & TNF $\alpha$ (NOD.SCID) & mRNA & Increased within 1 h post incubation & \\
\hline & & IFN $\gamma(\mathrm{NOD} . \mathrm{SCID})$ & mRNA & Increased within $1 \mathrm{~h}$ post incubation & \\
\hline & & Baseline (NOD) & mRNA & Detected at day 50 days of age & \\
\hline & & Pregnancy (C57BL/6J, CD-1) & mRNA & Increased by day 14.5 of pregnancy & (24) \\
\hline & NIT-1 mouse & $\mathrm{IL}-1 \beta$ & mRNA & Peak at $1 \mathrm{~h}$ post incubation & $(16)$ \\
\hline & $\beta$-cell line & $\mathrm{TNF} \alpha$ & mRNA & Peak at $1 \mathrm{~h}$ post incubation & \\
\hline & & $\mathrm{IFN} \alpha$ & mRNA & Not different compared to baseline & \\
\hline & & $\mathrm{IFN} \gamma$ & mRNA & Peak at $1 \mathrm{~h}$ post incubation & \\
\hline
\end{tabular}


pathways in $\beta$-cells besides $\mathrm{GH}$, some of which could enhance glucose-stimulated insulin secretion.

Suppressors of cytokine signaling-3 is important for how leptin affects insulin production by $\beta$-cells. Leptin is a hormone synthesized by white adipose tissue that regulates body fat mass by controlling appetite and energy expenditure through effects on the hypothalamus [reviewed in Ref. (38)]. Findings that leptin-deficient $o b / o b$ mice and leptin receptor-defective $d b /$ $d b$ mice develop hyperinsulinelima before the onset of a type 2 diabetes phenotype led to discoveries that leptin also inhibits preproinsulin gene expression by $\beta$-cells (39-41). SOCS-3 has been established as a mediator of central leptin resistance (25, 42). Laubner et al. found that SOCS-3 is also important for leptinmediated repression of insulin production in $\beta$-cells, the purpose of which is probably to adjust glucose homeostasis to the amount of body fat (20). Using the rat insulinoma cell line INS-1, it was demonstrated that leptin signaling in $\beta$-cells stimulates leptin receptor associated JAK2 tyrosine kinase activity that phosphorylates STAT3 and STAT5b, which bind to the SOCS-3 promoter inducing transcription. SOCS-3 in turn inhibits JAK-STAT signaling that is required for insulin expression. Dysregulation of SOCS-3 signaling may contribute to the development of type 2 diabetes in obese individuals whose $\beta$-cells become resistant to leptin signaling, leading to chronic insulin hypersecretion that eventually causes $\beta$-cell failure.

Suppressors of cytokine signaling molecules appear to protect against the impaired insulin secretion by $\beta$-cells exposed to proinflammatory cytokines. Previous studies have shown that IFN $\gamma$ reduces glucose-stimulated insulin secretion in $\beta$-cell lines as well as rodent and human islets (43-45). Cottet et al. assessed whether overexpressing SOCS-1 in the insulin-secreting cell line, $\beta$ Tc-Tet, could inhibit the IFN $\gamma$-driven JAK-STAT signal transduction pathway and prevent IFN $\gamma$-induced reductions in insulin gene expression and secretion (46). Constitutive SOCS-1 expression blocked phosphorylation and nuclear translocation of STAT-1 compared to non-transduced $\beta$ Tc-Tet cells, and IFN $\gamma$-induced reductions in insulin mRNA levels and glucose-stimulated insulin secretion were prevented. These findings differed from a later study that showed no effects of SOCS-1 overexpression on cytokine-induced inhibition of glucose-stimulated insulin secretion using primary islets from mice transgenically overexpressing SOCS-1 that were incubated with different concentrations of glucose and a mixture of IL-1 $\beta$, TNF $\alpha$, and IFN $\gamma$ (47). Possible reasons for this discrepancy are that the studies used different sources of $\beta$-cells, IFN $\gamma$ concentrations, culture conditions, and the origin and expression levels of SOCS-1 were also different.

Apart from regulating insulin expression, SOCS molecules may play a role in the desensitization of $\beta$-cells to autocrine/paracrine insulin signaling that follows prolonged glucose exposure. The chronic hyperglycemia and inflammatory cytokines that accompany type 2 diabetes are known to cause $\beta$-cells to become resistant to insulin signaling (48-51), which is usually required for normal $\beta$-cell functioning and survival $(52,53)$. The involvement of SOCS in this phenomenon has been investigated because SOCS molecules cause insulin resistance in other insulin-sensitive tissues that are exposed to inflammatory cytokines (54). A link between SOCS-1 and glucose-attenuated insulin signaling was demonstrated by Venieratos et al. who showed that prolonged exposure of the $\beta$-cell line $\beta$ Tc- 6 to high glucose concentrations inhibited insulin-induced tyrosine phosphorylation of the insulin receptor (IR), IR substrate-2 (IRS-2), as well as PI3-kinase activation (55). These impairments were associated with enhanced endogenous interleukin- $1 \beta$ (IL- $1 \beta$ ) by $\beta$ TC- 6 cells that, in turn, stimulated expression of SOCS-1. SOCS-1 was critical for desensitization of $\beta$-cells to insulin signaling because specific ablation of this molecule by small interfering RNA restored insulin signaling suppressed by high glucose. Although these authors found no effect of high glucose on SOCS-3 expression, another study demonstrated that SOCS-3 had very similar effects to SOCS-1 for inhibiting insulin signaling in RINm5F cells, a rat pancreatic $\beta$-cell line, after exposure to IL-1 $\beta$ (17).

The role of SOCS family members besides SOCS-1 and SOCS-3 for regulating insulin production and signaling in $\beta$-cells remains unclear. Conditional $\beta$-cells ablation of CIS showed no non-redundant functions for this gene (24). Another study investigated the importance of SOCS-2 and found no difference in glucose-induced insulin secretion in islets isolated from SOCS-2 knockout (KO) mice compared to wild-type controls (56). SOCS-2-KO mice were also normal for insulin and glucose tolerance. However, a separate report showed that transgenic mice constitutively expressing SOCS-2 in $\beta$-cells develop severe defects in glucose metabolism that were attributed to profoundly altered insulin secretion to various secretagogues, perturbed $\mathrm{Ca}$ flux in response to glucose, and impaired proinsulin maturation (57). While these results could indicate a role for SOCS- 2 in $\beta$-cell function, it is possible that the defects observed were artifacts related to the transgenic overexpression of SOCS-2 protein off the insulin promoter, which has caused similar disruptions in a variety of pancreasspecific gene manipulations $(58,59)$.

\section{SOCS REGULATION OF CYTOKINE SIGNALING AND $\beta$-CELL APOPTOSIS}

Suppressors of cytokine signaling proteins play a central role for regulating how $\beta$-cells respond to cytokines. Proinflammatory cytokines, such as IFN $\gamma, \mathrm{IL}-1 \beta$, and TNF $\alpha$, are secreted by lymphocytes and macrophages within pancreatic infiltrates during T1D development and after allogeneic islet transplantation and contribute to $\beta$-cell destruction by inducing a variety of pro-apoptotic processes $(60,61)$. SOCS-1 and SOCS-3 buffer $\beta$-cells against these effects by downregulating pro-inflammatory cytokine-signaling pathways. Besides understanding the natural effects of SOCS proteins in $\beta$-cells, there exists considerable interest in enhancing expression of these molecules to mitigate cytokine effects during T1D and after islet transplantation. Most of what is known about how SOCS proteins modulate $\beta$-cell cytokine responses has been discovered by a small number of researchers. A summary of their findings is described below. 


\section{Suppressors of Cytokine Signaling-1}

In the early 2000s, studies were conducted to determine whether SOCS-1 was involved in protecting $\beta$-cells against the pro-apoptotic effects of IFN $\gamma$. These were motivated by reports showing that IFN $\gamma$ induces SOCS-1 that negatively regulated JAK/STAT signaling in a wide variety of cell types $(62,63)$. Chong et al. showed that SOCS-1 overexpression in NIT-1 cells inhibited IFN $\gamma$ signaling, which blocked STAT-1 activation and IFN $\gamma$-induced apoptosis (16). However, natural expression of SOCS-1 did not affect the kinetics and intensity of IFN $\gamma$-signaling in primary $\beta$-cells, suggesting that SOCS-1 might not be involved in regulating inflammatory cytokines under physiological conditions. However, it was subsequently found that $\beta$-cells from SOCS-1-KO mice were more susceptible to cell death when exposed to IFN $\gamma$ in combination with TNF $\alpha$ compared to islets from wild-type mice (64). TNF $\alpha$ does not activate the JAK-STAT pathway. Thus, increased TNF $\alpha+$ IFN $\gamma$ induced cell death in SOCS-1 (KO) islets may have been the result of hypersensitivity to TNF $\alpha$-stimulated iNOS expression and nitric oxide (NO) production via dysregulation of the $\mathrm{p} 38$ mitogen-activated protein kinase pathway. TNF $\alpha$ alone did not induce iNOS expression or cell death, indicating that the pathways stimulated by IFN $\gamma$ are still necessary for iNOS induction in SOCS-1-KO $\beta$-cells. Similar results were obtained by Cottet et al. who showed that SOCS-1 overexpression prevents iNOS expression and apoptosis in $\beta$ Tc-Tet cells exposed to IFN $\gamma$ in combination with TNF $\alpha$ and IL-1 $\beta$ (46).

More recent studies have employed SOCS- 1 transgenic mice to examine how SOCS-1 overexpression affects $\beta$-cell resistance against spontaneous T1D and allogeneic transplantation. Flodström-Tullberg et al. found that spontaneous T1D was reduced in SOCS-1 transgenic NOD mice and that protection was associated with cytokine-induced STAT-1 phosphorylation within $\beta$-cells (65). Chong et al. obtained similar results showing that rat insulin promoter-driven SOCS- 1 expression in $\beta$-cells prevents progression to diabetes in NOD mice and $\mathrm{CD} 8^{+} \mathrm{TCR}$ transgenic NOD.NY8.3 mice (66). Another study demonstrated that SOCS-1 transgenic mice are protected from virally induced $\mathrm{CD}^{+} \mathrm{T}$ cell-mediated T1D (67). In transplantation studies, islets from C57BL6 (B6) SOCS-1 transgenic mice survived longer than wild-type islets when engrafted into allogeneic BALB/c recipient mice (68). The same SOCS-1 transgenic islets did not survive better than controls when transplanted into clinically diabetic NOD mice, probably because of already high circulating levels of autoreactive T cells. Another report found that SOCS-1 overexpression induced by an adenovirus system increased the survival of rat islets transplanted into allogeneic recipients with streptozotocin-induced diabetes (69).

Follow-up studies have identified several mechanisms through which SOCS-1 overexpression may improve $\beta$-cell survival in diabetes and islet transplantation models. Chong et al. showed that SOCS-1 inhibits IFN $\gamma$ and TNF $\alpha$-induced Fas and IL-15 expression by $\beta$-cells (66). In this way, SOCS- 1 may prevent $\mathrm{CD} 8^{+} \mathrm{T}$ cells from killing $\beta$-cells through Fas-Fas ligand interactions and reduce IL-15-mediated homing and activation of diabetogenic T cells within the pancreas. Another group found that SOCS-1 transgenic islets express less of the IFN $\gamma$ inducible chemokine Cxcl10 that is usually produced by islets during diabetes development and may be involved in recruitment of autoreactive $\mathrm{T}$ cells to the inflamed pancreas (70). Using islets from SOCS-1 transgenic mice on the B6 background, Zaitseva et al. demonstrated that SOCS-1 may block cytokine-mediated islet apoptosis by decreasing IFN $\gamma$, TNF $\alpha$, IL- $1 \beta$-induced caspase-3, -8, and -9 expression in $\beta$-cells (47). Usually, caspase- 3 activation, which can be initiated by caspases 8 and 9 , is essential for the induction of apoptosis in $\beta$-cells $(71,72)$. Unlike previous reports, these authors found no evidence that SOCS-1 prevents cytokine-mediated NO production and suggested that changes in NO production might not contribute to the protective effect of SOCS- 1 overexpression in $\beta$-cells. In a separate report, Solomon et al. showed that transgenic expression of SOCS- 1 rendered islets resistant to IFN $\gamma$ and TNF $\alpha$-induced cell death and that resistance was correlated with a significant inhibition of the transcription factor interferon regulatory factor-1 (IRF-1) (73). They proposed a model in which SOCS-1 prevents cytokines from inducing IRF-1 that normally inhibits anti-apoptotic proteins, such as Bcl-2 and Bcl-xL, by blocking the cytoprotective NFkB pathway (74-76). Several studies have found that SOCS-1 reduces $\beta$-cell expression of class I MHC molecules following exposure to pro-inflammatory cytokines $(16,66,67,73)$. IFN $\gamma$ produced during allograft rejection and T1D development is known to upregulate class I MHC antigen on $\beta$-cells, which makes them more vulnerable to lysis by $\mathrm{CD} 8^{+} \mathrm{T}$ cells. SOCS-1 overexpression was demonstrated to reduce class I MHC expression by pancreatic islets incubated with IFN $\gamma$ and TNF $\alpha$ and after LCMV infection (67). One report showed that physiological levels of SOCS-1 protein are sufficient to reduce class I MHC expression following cytokine exposure, because SOCS-1-deficient $\beta$-cells were more sensitive to TNF $\alpha$-induced class I MHC expression compared to wild-type islets (64).

\section{Suppressors of Cytokine Signaling-3}

Different research groups using similar model systems published reports characterizing SOCS-1 and SOCS-3 regulation of $\beta$-cell cytokine signaling, concurrently. An early study by Karlsen et al. used INS-1 cells with doxycycline (DOX)inducible SOCS-3 expression to show that the apoptotic effects of IL- $1 \beta$ and IFN $\gamma$ were, respectively, fully and partially blocked by SOCS-3 overexpression at moderate and high concentrations of both cytokines (21). The protective effects of SOCS-3 overexpression were correlated with decreased IL-1 $\beta$-induced iNOS promoter activity and NO production. In primary islet cells from rats and humans, SOCS-3 mRNA expression was induced by exposure to IL- $1 \beta$ alone and in combination with IFN $\gamma$ and $\mathrm{TNF} \alpha$, indicating that SOCS-3 might contribute to the natural resistance of islets against the toxic effects of pro-inflammatory cytokines $(19,21)$.

A number of mechanisms have been identified, in addition to reduced NO production, through which SOCS-3 overexpression may protect islets from cytokine-mediated apoptosis. By comparing global gene expression following IL- $1 \beta$ exposure of INS-1 cells with and without DOX-induced SOCS-3 expression, 
it was found that multiple IL- $1 \beta$-induced NFkB-dependent early apoptotic and immune genes were inhibited, including ICAM, complement C3, Mob-1, MIP-1, CX3C, NFkB-p105, IRF-1, and fibrinogen- $\gamma$ (77). In a separate study, DOX-inducible SOCS-3 INS-1 cells and primary rat islets transduced with a SOCS-3encoding adenovirus showed that IL- $1 \beta$-induced expression of Fas and the chemokines Mcp-1, Mip-2, and St-38, which depend on the NFKB pathway, become inhibited by SOCS-3 overexpression (78). Collectively, these results suggest that by blocking NFKB activity, SOCS- 3 may protect $\beta$-cells from attracting, engaging, and activating autoreactive $\mathrm{T}$ cells.

Suppressors of cytokine signaling- 3 overexpression partially protects $\beta$-cells from immune responses that develop after allogeneic transplantation. Rønn et al. showed that islets from B6 mice with $\beta$-cell-specific SOCS-3 expression survived longer compared to wild-type islets when transplanted into $\mathrm{BALB} / \mathrm{c}$ mice (19). However, the same transgenic islets did not survive better than wild-type islets when transplanted into spontaneously diabetic NOD mice. Outcomes of these transplantation studies are remarkably similar to experiments using SOCS-1 transgenic islets $(68,69)$ and demonstrate that SOCS-3 expression can also protect islets against allogeneic $\mathrm{MHC}$ responses but cannot circumvent the autoimmune responses that develop in the NOD mouse. It is not yet known whether SOCS-3 transgenic expression impacts spontaneous diabetes. However, one report examined whether $\beta$-cell-specific SOCS-3 expression could protect B6 mice from multiple low-dose streptozotocin-induced diabetes development (79). Surprisingly, SOCS-3 transgenic mice tended to develop accelerated disease compared to wild-type controls. To explain their findings, the authors proposed that increased SOCS-3 expression might, under some conditions, lead to a failed upregulation of protective pathways that would normally become activated after $\beta$-cell exposure to inflammatory cytokines. In support of this hypothesis, the investigators showed that SOCS-3 overexpression in mouse and rat islets reduced IL-1 $\beta$-induced expression of IL-1 $\alpha$, a glycolipid that antagonizes IL-1 $\beta$-induced $\beta$-cell damage (80). Another explanation for the increased sensitivity of SOCS-3 transgenic mice to MLDSTZinduced diabetes is that SOCS-3 overexpression could obstruct normal $\beta$-cell functioning, for instance, by interfering with JAK/ STAT-dependent insulin signaling.

Although much emphasis has been placed on understanding SOCS- 3 modulation of IL- $1 \beta$ and IFN $\gamma$ signaling in $\beta$-cells, Bruun et al. demonstrated that SOCS-3 expression also inhibits TNF $\alpha$ signaling (81). They further showed that TNF $\alpha$ transiently induces the expression of SOCS-3 mRNA in primary rat $\beta$-cells, through stimulating NFkB and MAP kinases. Apoptosis mediated by TNF $\alpha$ alone or in combination with IL- $1 \beta$ was suppressed by overexpression of SOCS-3 in INS-1 cells by repressing TNF $\alpha$-induced I $\mathrm{B}$ degradation, NFкB DNA binding, and NFKB-transcription of MnSOD, a classical example of an NFкB responsive gene.

Overexpression studies have established that SOCS-3 is capable of regulating signaling induced by at least three major cytokines involved in the pathogenesis of T1D. Consequently, SOCS-3 represents a promising target for therapeutic interventions to protect $\beta$-cell mass. However, unlike SOCS-1, there is little known about how SOCS-3 contributes to the natural resistance of $\beta$-cells against cytokine-mediated toxicity, in part, because data are lacking about SOCS-3-deficient $\beta$-cells. SOCS- 2 is also expressed in $\beta$-cells, but the role of this SOCS member on $\beta$-cell apoptosis has yet to be firmly established. Puff et al. reported that IL-1 $\beta$-mediated cell death in vitro was unchanged after siRNA mediated SOCS-2 knockdown in INS-1E cells. Also, destruction of $\beta$-cells after MLDSTZ injections was not altered in SOCS-2-KO mice (56). In contrast, Alkharusi et al. showed that 6-month-old, but not 2-month-old, SOCS-2-KO mice were less sensitive to the effects of MLDSTZ treatment (82).

\section{SOCS PROTEINS MODULATE $\beta$-CELL GROWTH AND REPLICATION}

Growth hormone and prolactin (PRL) are hormones that stimulate $\beta$-cell replication through JAK-STAT-signaling receptors that are subject to suppression by SOCS proteins (83-88). Both $\mathrm{GH}$ and $\mathrm{PRL}$ stimulate $\beta$-cell growth and proliferation in vitro (84, 89, 90). Furthermore, mice deficient for PRL receptor (PRLR) develop smaller $\beta$-cells and reduced pancreatic insulin content compared to wild-type controls (91). $\beta$-cell-specific GH receptor knockout (GHRKO) mice develop normal $\beta$-cell mass when raised on a standard chow diet (30). However, they exhibit a dramatic defect in $\beta$-cell hyperplasia when fed a high-fat diet (HFD), indicating that GH may be dispensable for normal $\beta$-cell development but required for $\beta$-cell compensatory growth in response to HFD challenge.

Pancreatic islets modulate expression of receptors for $\mathrm{GH}$ and PRL during periods of $\beta$-cell expansion, such as during development, pregnancy, and lactation $(87,88,92)$. It has been reported that SOCS proteins inhibit GH- and PRL-mediated signal transduction and proliferation in multiple tissue types $(31,33,93)$, which prompted studies to investigate whether SOCS molecules also suppress GH- and PRL-mediated growth in $\beta$-cells. Rønn et al. investigated the role of SOCS signaling in the $\beta$-cells lines RIN-5AH and INS-1 with inducible SOCS-3 expression (28). In a dose-dependent way, SOCS-3 inhibited GH-induced DNA binding of both STAT3 and STAT5 in RIN-5AH cells stably transfected with a ponasterone-inducible SOCS-3 expression system. 5-bromodeoxyuridine (BrdU) incorporation was used to show that SOCS-3 inhibits GH-induced proliferation of INS-1 cells in a dose-dependent manner with DOX-inducible expression of SOCS-3. Lindberg et al. examined the in vivo effects of specific transgenic overexpression of SOCS-3 in $\beta$-cells (37). In spite of large variation in SOCS-3 transgene expression, $\beta$-cell volume of transgenic mice was reduced by approximately 30\% compared with $\beta$-cell volume in wild-type female mice. There was no difference in $\beta$-cell volume between male and female mice in either group or between male transgenic mice and male wild-type littermates. This may have been because $\beta$-cell volume in wild-type female mice is usually relatively large compared to male mice, and, therefore, SOCS-3 overexpression may have had a more pronounced effect on female than on male mice. SOCS-3 overexpression had no effect on the amount of proliferating $\beta$-cells, probably because inhibition of GH and/or PRL happened at an earlier stage 
of development than when the mice were analyzed ( 2 months of age) (88). Transduction of primary neonatal rat islet cultures with recombinant adenoviruses expressing various SOCS proteins, followed by stimulation with $\mathrm{GH}$, demonstrated that SOCS-3 inhibits islet proliferation by $\mathrm{GH}$ (37). The effect appeared to be specific for SOCS-3, as SOCS-1, SOCS-2, or CIS expression did not affect $\mathrm{GH}$-induced $\beta$-cell proliferation. Additional studies using SOCS-2-deficient (56) and SOCS-2 overexpressing mice (57) appear to rule out that SOCS-2 is involved in $\beta$-cell hypertrophy or replication.

Hormones besides GH and PRL induce $\beta$-cell growth. Some of these, such as placental lactogen $(83,87,94)$ and glucagon-like peptide-1 (95), signal independently of the JAK/STAT pathway and are not subject to inhibition by SOCS molecules. SOCS proteins may regulate IR signaling that employs the JAK/STAT pathway and which appears to be important for maintaining adult $\beta$-cell mass (96) and inducing compensatory $\beta$-cell proliferation during HFD challenge (97). This question remains to be answered by future studies.

\section{CONCLUSION}

The discovery that SOCS proteins are expressed in $\beta$-cells and interactively regulate a diverse range of signaling pathways has greatly advanced our understanding about how $\beta$-cell growth, function, and survival are controlled. They also provide insight about how $\beta$-cells manage to simultaneously regulate often contradictory signaling pathways for different families of receptors, i.e., IR, GH/PRL receptors, leptin receptors, and cytokine receptors. Figure 1 describes some of these pathways. Although

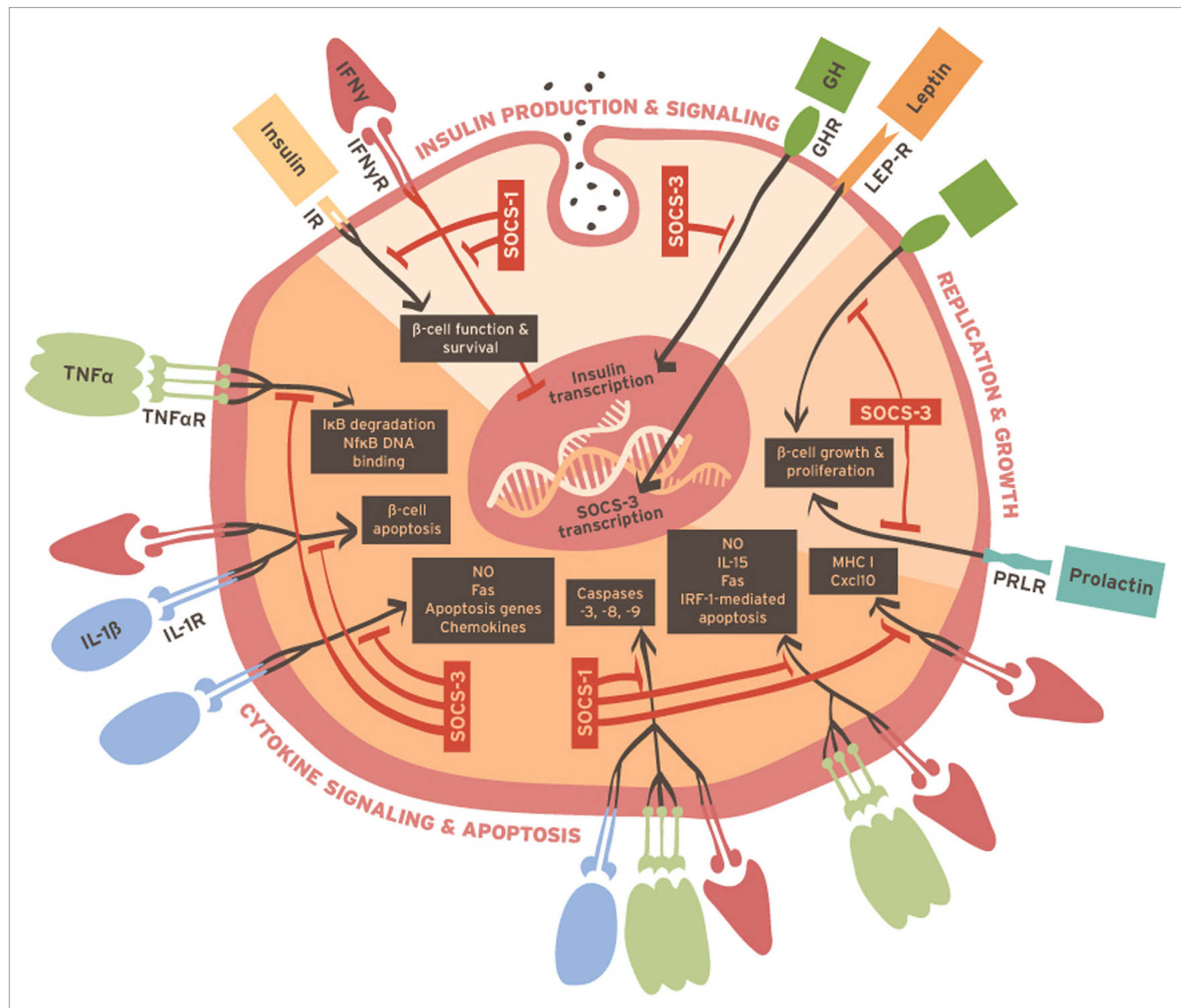

FIGURE 1 | Summary of cellular processes involved in $\beta$-cell function, survival, and replication that are reportedly regulated by SOCS molecules. 
considerable progress has been achieved, gaps remain in our understanding about the natural role of SOCS in $\beta$-cells, which is partly due to a reliance on genetically modified mice or cell lines that express non-physiological levels of SOCS proteins compared to primary $\beta$-cells. Nevertheless, important information has been gleaned from diverse model systems about the possibility of therapeutically harnessing SOCS proteins to improve the function and survival of $\beta$-cells in vivo and for propagating and differentiating $\beta$-cells in vitro for transplantation. These discoveries represent important advances toward better treatments for diabetes.

\section{REFERENCES}

1. Kulkarni RN. The islet beta-cell. Int J Biochem Cell Biol (2004) 36(3):365-71. doi:10.1016/j.biocel.2003.08.010

2. Donath MY, Shoelson SE. Type 2 diabetes as an inflammatory disease. Nat Rev Immunol (2011) 11(2):98-107. doi:10.1038/nri2925

3. Bending D, Zaccone P, Cooke A. Inflammation and type one diabetes. Int Immunol (2012) 24(6):339-46. doi:10.1093/intimm/dxs049

4. Stewart AF, Hussain MA, García-Ocaña A, Vasavada RC, Bhushan A, BernalMizrachi E, et al. Human $\beta$-cell proliferation and intracellular signaling: part 3. Diabetes (2015) 64(6):1872-85. doi:10.2337/db14-1843

5. Naka T, Narazaki M, Hirata M, Matsumoto T, Minamoto S, Aono A, et al. Structure and function of a new STAT-induced STAT inhibitor. Nature (1997) 387(6636):924-9. doi:10.1038/43219

6. Starr R, Willson TA, Viney EM, Murray LJ, Rayner JR, Jenkins BJ, et al. A family of cytokine-inducible inhibitors of signalling. Nature (1997) 387(6636):917-21. doi:10.1038/43206

7. Endo TA, Masuhara M, Yokouchi M, Suzuki R, Sakamoto H, Mitsui K, et al. A new protein containing an $\mathrm{SH} 2$ domain that inhibits JAK kinases. Nature (1997) 387(6636):921-4. doi:10.1038/43213

8. Yoshimura A, Ohkubo T, Kiguchi T, Jenkins NA, Gilbert DJ, Copeland NG, et al. A novel cytokine-inducible gene CIS encodes an SH2-containing protein that binds to tyrosine-phosphorylated interleukin 3 and erythropoietin receptors. EMBO J (1995) 14(12):2816-26.

9. Zhang JG, Farley A, Nicholson SE, Willson TA, Zugaro LM, Simpson RJ, et al. The conserved SOCS box motif in suppressors of cytokine signaling binds to elongins $\mathrm{B}$ and $\mathrm{C}$ and may couple bound proteins to proteasomal degradation. Proc Natl Acad Sci U S A (1999) 96(5):2071-6. doi:10.1073/ pnas.96.5.2071

10. Hilton DJ, Richardson RT, Alexander WS, Viney EM, Willson TA, Sprigg NS, et al. Twenty proteins containing a C-terminal SOCS box form five structural classes. Proc Natl Acad Sci U S A (1998) 95(1):114-9. doi:10.1073/ pnas.95.1.114

11. Kamura T, Sato S, Haque D, Liu L, Kaelin WG, Conaway RC, et al. The elongin $\mathrm{BC}$ complex interacts with the conserved SOCS-box motif present in members of the SOCS, ras, WD-40 repeat, and ankyrin repeat families. Genes Dev (1998) 12(24):3872-81. doi:10.1101/gad.12.24.3872

12. Zhang JG, Metcalf D, Rakar S, Asimakis M, Greenhalgh CJ, Willson TA, et al. The SOCS box of suppressor of cytokine signaling-1 is important for inhibition of cytokine action in vivo. Proc Natl Acad Sci U S A (2001) 98(23):13261-5. doi:10.1073/pnas.231486498

13. Croker BA, Kiu H, Nicholson SE. SOCS regulation of the JAK/STAT signalling pathway. Semin Cell Dev Biol (2008) 19(4):414-22. doi:10.1016/j. semcdb.2008.07.010

14. Yoshimura A, Yasukawa H. JAK's SOCS: a mechanism of inhibition. Immunity (2012) 36(2):157-9. doi:10.1016/j.immuni.2012.01.010

15. Santangelo C, Scipioni A, Marselli L, Marchetti P, Dotta F. Suppressor of cytokine signaling gene expression in human pancreatic islets: modulation by cytokines. Eur J Endocrinol (2005) 152(3):485-9. doi:10.1530/eje.1.01856

16. Chong MM, Thomas HE, Kay TW. Gamma-Interferon signaling in pancreatic beta-cells is persistent but can be terminated by overexpression of suppressor of cytokine signaling-1. Diabetes (2001) 50(12):2744-51. doi:10.2337/ diabetes.50.12.2744

\section{AUTHOR CONTRIBUTIONS}

CY and JD co-wrote and edited the manuscript.

\section{ACKNOWLEDGMENTS}

The authors thank Drs. Dave Serreze, Yi-Guang Chen, and Joseph Larkin III for their helpful discussion. CY and JD were supported by the American Diabetes Association (1-14-BS-051). The authors also thank Ms. Stacey Jones for her assistance with graphic design.

17. Emanuelli B, Glondu M, Filloux C, Peraldi P, Van Obberghen E. The potential role of SOCS-3 in the interleukin-1beta-induced desensitization of insulin signaling in pancreatic beta-cells. Diabetes (2004) 53(Suppl 3):S97-103. doi:10.2337/diabetes.53.suppl_3.S97

18. Rieneck K, Bovin LF, Josefsen K, Buschard K, Svenson M, Bendtzen K. Massive parallel gene expression profiling of RINm5F pancreatic islet betacells stimulated with interleukin-1beta. APMIS (2000) 108(12):855-72. doi:10.1111/j.1600-0463.2000.tb00009.x

19. Rønn SG, Börjesson A, Bruun C, Heding PE, Frobøse H, Mandrup-Poulsen $\mathrm{T}$, et al. Suppressor of cytokine signalling-3 expression inhibits cytokine-mediated destruction of primary mouse and rat pancreatic islets and delays allograft rejection. Diabetologia (2008) 51(10):1873-82. doi:10.1007/ s00125-008-1090-0

20. Laubner K, Kieffer TJ, Lam NT, Niu X, Jakob F, Seufert J. Inhibition of preproinsulin gene expression by leptin induction of suppressor of cytokine signaling 3 in pancreatic beta-cells. Diabetes (2005) 54(12):3410-7. doi:10.2337/ diabetes.54.12.3410

21. Karlsen AE, Rønn SG, Lindberg K, Johannesen J, Galsgaard ED, Pociot F, et al. Suppressor of cytokine signaling 3 (SOCS-3) protects beta-cells against interleukin-1beta - and interferon-gamma-mediated toxicity. Proc Natl Acad Sci U S A (2001) 98(21):12191-6. doi:10.1073/pnas.211445998

22. Lv N, Song MY, Kim EK, Park JW, Kwon KB, Park BH. Guggulsterone, a plant sterol, inhibits NF-kappaB activation and protects pancreatic beta cells from cytokine toxicity. Mol Cell Endocrinol (2008) 289(1-2):49-59. doi:10.1016/j. mce.2008.02.001

23. Rieck S, White P, Schug J, Fox AJ, Smirnova O, Gao N, et al. The transcriptional response of the islet to pregnancy in mice. Mol Endocrinol (2009) 23(10):1702-12. doi:10.1210/me.2009-0144

24. Jiao Y, Rieck S, Le Lay J, Kaestner KH. CISH has no non-redundant functions in glucose homeostasis or beta cell proliferation during pregnancy in mice. Diabetologia (2013) 56(11):2435-45. doi:10.1007/s00125-013-3014-x

25. Bjørbaek C, Elmquist JK, Frantz JD, Shoelson SE, Flier JS. Identification of SOCS-3 as a potential mediator of central leptin resistance. Mol Cell (1998) 1(4):619-25. doi:10.1016/S1097-2765(00)80062-3

26. Nakata M, Okada T, Ozawa K, Yada T. Resistin induces insulin resistance in pancreatic islets to impair glucose-induced insulin release. Biochem Biophys Res Commun (2007) 353(4):1046-51. doi:10.1016/j.bbrc.2006.12.134

27. Gregorieff A, Pyronnet S, Sonenberg N, Veillette A. Regulation of SOCS-1 expression by translational repression. J Biol Chem (2000) 275(28):21596-604. doi:10.1074/jbc.M910087199

28. Rønn SG, Hansen JA, Lindberg K, Karlsen AE, Billestrup N. The effect of suppressor of cytokine signaling 3 on GH signaling in beta-cells. Mol Endocrinol (2002) 16(9):2124-34. doi:10.1210/me.2002-0082

29. Galsgaard ED, Gouilleux F, Groner B, Serup P, Nielsen JH, Billestrup N Identification of a growth hormone-responsive STAT5-binding element in the rat insulin 1 gene. Mol Endocrinol (1996) 10(6):652-60. doi:10.1210/ mend.10.6.8776725

30. Wu Y, Liu C, Sun H, Vijayakumar A, Giglou PR, Qiao R, et al. Growth hormone receptor regulates $\beta$ cell hyperplasia and glucose-stimulated insulin secretion in obese mice. J Clin Invest (2011) 121(6):2422-6. doi:10.1172/JCI45027

31. Ram PA, Waxman DJ. SOCS/CIS protein inhibition of growth hormone-stimulated STAT5 signaling by multiple mechanisms. JBiol Chem (1999) 274(50):35553-61. doi:10.1074/jbc.274.50.35553 
32. Hansen JA, Lindberg K, Hilton DJ, Nielsen JH, Billestrup N. Mechanism of inhibition of growth hormone receptor signaling by suppressor of cytokine signaling proteins. Mol Endocrinol (1999) 13(11):1832-43. doi:10.1210/ mend.13.11.0368

33. Adams TE, Hansen JA, Starr R, Nicola NA, Hilton DJ, Billestrup N. Growth hormone preferentially induces the rapid, transient expression of SOCS3, a novel inhibitor of cytokine receptor signaling. J Biol Chem (1998) 273(3):1285-7. doi:10.1074/jbc.273.3.1285

34. Galsgaard ED, Friedrichsen BN, Nielsen JH, Møldrup A. Expression of dominant-negative STAT5 inhibits growth hormone- and prolactin-induced proliferation of insulin-producing cells. Diabetes (2001) 50(Suppl 1):S40-1. doi:10.2337/diabetes.50.2007.S40

35. Friedrichsen BN, Galsgaard ED, Nielsen JH, Møldrup A. Growth hormoneand prolactin-induced proliferation of insulinoma cells, INS-1, depends on activation of STAT5 (signal transducer and activator of transcription 5). Mol Endocrinol (2001) 15(1):136-48. doi:10.1210/mend.15.1.0576

36. Friedrichsen BN, Richter HE, Hansen JA, Rhodes CJ, Nielsen JH, Billestrup N, et al. Signal transducer and activator of transcription 5 activation is sufficient to drive transcriptional induction of cyclin D2 gene and proliferation of rat pancreatic beta-cells. Mol Endocrinol (2003) 17(5):945-58. doi:10.1210/ me.2002-0356

37. Lindberg K, Rønn SG, Tornehave D, Richter H, Hansen JA, Rømer J, et al. Regulation of pancreatic beta-cell mass and proliferation by SOCS-3. J Mol Endocrinol (2005) 35(2):231-43. doi:10.1677/jme.1.01840

38. Park HK, Ahima RS. Physiology of leptin: energy homeostasis, neuroendocrine function and metabolism. Metabolism (2015) 64(1):24-34. doi:10.1016/j. metabol.2014.08.004

39. Coleman DL. Diabetes-obesity syndromes in mice. Diabetes (1982) 31(Suppl 1 Pt 2):1-6. doi:10.2337/diab.31.1.S1

40. Coleman DL. Obese and diabetes: two mutant genes causing diabetes-obesity syndromes in mice. Diabetologia (1978) 14(3):141-8. doi:10.1007/BF00429772

41. Chen NG, Romsos DR. Enhanced sensitivity of pancreatic islets from preobese 2-week-old ob/ob mice to neurohormonal stimulation of insulin secretion. Endocrinology (1995) 136(2):505-11. doi:10.1210/endo.136.2.7835283

42. Lubis AR, Widia F, Soegondo S, Setiawati A. The role of SOCS-3 protein in leptin resistance and obesity. Acta Med Indones (2008) 40(2):89-95.

43. Baldeón ME, Neece DJ, Nandi D, Monaco JJ, Gaskins HR. Interferon-gamma independently activates the MHC class I antigen processing pathway and diminishes glucose responsiveness in pancreatic beta-cell lines. Diabetes (1997) 46(5):770-8. doi:10.2337/diab.46.5.770

44. Rabinovitch A, Suarez-Pinzon WL, Shi Y, Morgan AR, Bleackley RC. DNA fragmentation is an early event in cytokine-induced islet beta-cell destruction. Diabetologia (1994) 37(8):733-8. doi:10.1007/BF00404328

45. Eizirik DL, Sandler S, Welsh N, Cetkovic-Cvrlje M, Nieman A, Geller DA, et al. Cytokines suppress human islet function irrespective of their effects on nitric oxide generation. J Clin Invest (1994) 93(5):1968-74. doi:10.1172/ JCI117188

46. Cottet S, Dupraz P, Hamburger F, Dolci W, Jaquet M, Thorens B. SOCS-1 protein prevents Janus kinase/STAT-dependent inhibition of beta cell insulin gene transcription and secretion in response to interferon-gamma. JBiol Chem (2001) 276(28):25862-70. doi:10.1074/jbc.M103235200

47. Zaitseva II, Hultcrantz M, Sharoyko V, Flodström-Tullberg M, Zaitsev SV, Berggren PO. Suppressor of cytokine signaling-1 inhibits caspase activation and protects from cytokine-induced beta cell death. Cell Mol Life Sci (2009) 66(23):3787-95. doi:10.1007/s00018-009-0151-y

48. Donath MY, Størling J, Maedler K, Mandrup-Poulsen T. Inflammatory mediators and islet beta-cell failure: a link between type 1 and type 2 diabetes. J Mol Med (Berl) (2003) 81(8):455-70. doi:10.1007/s00109-003-0450-y

49. Donath MY, Halban PA. Decreased beta-cell mass in diabetes: significance, mechanisms and therapeutic implications. Diabetologia (2004) 47(3):581-9. doi:10.1007/s00125-004-1336-4

50. Maedler K, Spinas GA, Lehmann R, Sergeev P, Weber M, Fontana A, et al. Glucose induces beta-cell apoptosis via upregulation of the Fas receptor in human islets. Diabetes (2001) 50(8):1683-90. doi:10.2337/diabetes.50.8.1683

51. Maedler K, Sergeev P, Ris F, Oberholzer J, Joller-Jemelka HI, Spinas GA, et al. Glucose-induced beta cell production of IL-1beta contributes to glucotoxicity in human pancreatic islets. J Clin Invest (2002) 110(6):851-60. doi:10.1172/ JCI15318
52. Kulkarni RN, Brüning JC, Winnay JN, Postic C, Magnuson MA, Kahn CR. Tissue-specific knockout of the insulin receptor in pancreatic beta cells creates an insulin secretory defect similar to that in type 2 diabetes. Cell (1999) 96(3):329-39. doi:10.1016/S0092-8674(00)80546-2

53. Withers DJ, Gutierrez JS, Towery H, Burks DJ, Ren JM, Previs S, et al. Disruption of IRS-2 causes type 2 diabetes in mice. Nature (1998) 391(6670):900-4. doi: $10.1038 / 36116$

54. Feng X, Tang H, Leng J, Jiang Q. Suppressors of cytokine signaling (SOCS) and type 2 diabetes. Mol Biol Rep (2014) 41(4):2265-74. doi:10.1007/ s11033-014-3079-8

55. Venieratos PD, Drossopoulou GI, Kapodistria KD, Tsilibary EC, Kitsiou PV. High glucose induces suppression of insulin signalling and apoptosis via upregulation of endogenous IL-1beta and suppressor of cytokine signalling-1 in mouse pancreatic beta cells. Cell Signal (2010) 22(5):791-800. doi:10.1016/j. cellsig.2010.01.003

56. Puff R, Dames P, Weise M, Göke B, Parhofer K, Lechner A. No non-redundant function of suppressor of cytokine signaling 2 in insulin producing $\beta$-cells. Islets (2010) 2(4):252-7. doi:10.4161/isl.2.4.12556

57. Lebrun P, Cognard E, Gontard P, Bellon-Paul R, Filloux C, Berthault MF, et al. The suppressor of cytokine signalling 2 (SOCS2) is a key repressor of insulin secretion. Diabetologia (2010) 53(9):1935-46. doi:10.1007/s00125-010-1786-9

58. Magnuson MA, Burlison JS. Caveats and considerations for performing pancreas-specific gene manipulations in the mouse. Diabetes Obes Metab (2007) 9(Suppl 2):5-13. doi:10.1111/j.1463-1326.2007.00771.x

59. Leiter EH, Reifsnyder P, Driver J, Kamdar S, Choisy-Rossi C, Serreze DV, et al. Unexpected functional consequences of xenogeneic transgene expression in beta-cells of NOD mice. Diabetes Obes Metab (2007) 9(Suppl 2):14-22. doi:10.1111/j.1463-1326.2007.00770.x

60. Kanak MA, Takita M, Kunnathodi F, Lawrence MC, Levy MF, Naziruddin B. Inflammatory response in islet transplantation. Int J Endocrinol (2014) 2014:451035. doi:10.1155/2014/451035

61. Padgett LE, Broniowska KA, Hansen PA, Corbett JA, Tse HM. The role of reactive oxygen species and proinflammatory cytokines in type 1 diabetes pathogenesis. Ann N Y Acad Sci (2013) 1281:16-35. doi:10.1111/j.1749-6632.2012.06826.x

62. Suzuki R, Sakamoto H, Yasukawa H, Masuhara M, Wakioka T, Sasaki A, et al. CIS3 and JAB have different regulatory roles in interleukin- 6 mediated differentiation and STAT3 activation in M1 leukemia cells. Oncogene (1998) 17(17):2271-8. doi:10.1038/sj.onc.1202143

63. Sakamoto H, Yasukawa H, Masuhara M, Tanimura S, Sasaki A, Yuge K, et al. A Janus kinase inhibitor, JAB, is an interferon-gamma-inducible gene and confers resistance to interferons. Blood (1998) 92(5):1668-76.

64. Chong MM, Thomas HE, Kay TW. Suppressor of cytokine signaling-1 regulates the sensitivity of pancreatic beta cells to tumor necrosis factor. J Biol Chem (2002) 277(31):27945-52. doi:10.1074/jbc.M110214200

65. Flodström-Tullberg M, Yadav D, Hägerkvist R, Tsai D, Secrest P, Stotland A, et al. Target cell expression of suppressor of cytokine signaling-1 prevents diabetes in the NOD mouse. Diabetes (2003) 52(11):2696-700. doi:10.2337/ diabetes.52.11.2696

66. Chong MM, Chen Y, Darwiche R, Dudek NL, Irawaty W, Santamaria P, et al. Suppressor of cytokine signaling-1 overexpression protects pancreatic beta cells from CD8+ T cell-mediated autoimmune destruction. J Immunol (2004) 172(9):5714-21. doi:10.4049/jimmunol.172.9.5714

67. Barral AM, Thomas HE, Ling EM, Darwiche R, Rodrigo E, Christen U, et al. SOCS-1 protects from virally-induced CD8 T cell mediated type 1 diabetes. J Autoimmun (2006) 27(3):166-73. doi:10.1016/j.jaut.2006.08.002

68. Solomon M, Flodström-Tullberg M, Sarvetnick N. Differences in suppressor of cytokine signaling-1 (SOCS-1) expressing islet allograft destruction in nor$\mathrm{mal} \mathrm{BALB/c}$ and spontaneously-diabetic NOD recipient mice. Transplantation (2005) 79(9):1104-9. doi:10.1097/01.TP.0000162979.66954.53

69. Qin J, Jiao Y, Chen X, Zhou S, Liang C, Zhong C. Overexpression of suppressor of cytokine signaling 1 in islet grafts results in anti-apoptotic effects and prolongs graft survival. Life Sci (2009) 84(23-24):810-6. doi:10.1016/j. lfs.2009.03.010

70. Hultcrantz M, Jacobson S, Hill NJ, Santamaria P, Flodström-Tullberg M. The target cell response to cytokines governs the autoreactive $\mathrm{T}$ cell repertoire in the pancreas of NOD mice. Diabetologia (2009) 52(2):299-305. doi:10.1007/ s00125-008-1193-7 
71. Augstein P, Bahr J, Wachlin G, Heinke P, Berg S, Salzsieder E, et al. Cytokines activate caspase- 3 in insulinoma cells of diabetes-prone NOD mice directly and via upregulation of Fas. J Autoimmun (2004) 23(4):301-9. doi:10.1016/j. jaut.2004.09.006

72. Riedl SJ, Shi Y. Molecular mechanisms of caspase regulation during apoptosis. Nat Rev Mol Cell Biol (2004) 5(11):897-907. doi:10.1038/nrm1496

73. Solomon M, Flodström-Tullberg M, Sarvetnick N. Beta-cell specific expression of suppressor of cytokine signaling-1 (SOCS-1) delays islet allograft rejection by down-regulating Interferon Regulatory Factor-1 (IRF-1) signaling. Transpl Immunol (2011) 24(3):181-8. doi:10.1016/j.trim.2010.11.007

74. Zong WX, Edelstein LC, Chen C, Bash J, Gélinas C. The prosurvival Bcl-2 homolog Bfl-1/A1 is a direct transcriptional target of NF-kappaB that blocks TNFalpha-induced apoptosis. Genes Dev (1999) 13(4):382-7. doi:10.1101/ gad.13.4.382

75. Chen C, Edelstein LC, Gélinas C. The Rel/NF-kappaB family directly activates expression of the apoptosis inhibitor Bcl-x(L). Mol Cell Biol (2000) 20(8):2687-95. doi:10.1128/MCB.20.8.2687-2695.2000

76. Catz SD, Johnson JL. Transcriptional regulation of bcl-2 by nuclear factor kappa B and its significance in prostate cancer. Oncogene (2001) 20(50):7342-51. doi:10.1038/sj.onc. 1204926

77. Karlsen AE, Heding PE, Frobøse H, Rønn SG, Kruhøffer M, Orntoft TF, et al. Suppressor of cytokine signalling (SOCS)-3 protects beta cells against IL-1beta-mediated toxicity through inhibition of multiple nuclear factor-kappaB-regulated proapoptotic pathways. Diabetologia (2004) 47(11):1998-2011. doi:10.1007/s00125-004-1568-3

78. Jacobsen ML, Rønn SG, Bruun C, Larsen CM, Eizirik DL, Mandrup-Poulsen T, et al. IL-1beta-induced chemokine and Fas expression are inhibited by suppressor of cytokine signalling-3 in insulin-producing cells. Diabetologia (2009) 52(2):281-8. doi:10.1007/s00125-008-1199-1

79. Börjesson A, Rønn SG, Karlsen AE, Billestrup N, Sandler S. $\beta$-cell specific overexpression of suppressor of cytokine signalling-3 does not protect against multiple low dose streptozotocin induced type 1 diabetes in mice. Immunol Lett (2011) 136(1):74-9. doi:10.1016/j.imlet.2010.12.007

80. Dinarello CA. The role of the interleukin-1-receptor antagonist in blocking inflammation mediated by interleukin-1. N Engl J Med (2000) 343(10):732-4. doi:10.1056/NEJM200009073431011

81. Bruun C, Heding PE, Rønn SG, Frobøse H, Rhodes CJ, Mandrup-Poulsen T, et al. Suppressor of cytokine signalling-3 inhibits tumor necrosis factor-alpha induced apoptosis and signalling in beta cells. Mol Cell Endocrinol (2009) 311(1-2):32-8. doi:10.1016/j.mce.2009.07.019

82. Alkharusi A, Mirecki-Garrido M, Ma Z, Zadjali F, Flores-Morales A, Nyström $\mathrm{T}$, et al. Suppressor of cytokine signaling 2 (SOCS2) deletion protects against multiple low dose streptozotocin-induced type 1 diabetes in adult male mice. Horm Mol Biol Clin Investig (2015). doi:10.1515/hmbci-2015-0036

83. Nielsen JH. Effects of growth hormone, prolactin, and placental lactogen on insulin content and release, and deoxyribonucleic acid synthesis in cultured pancreatic islets. Endocrinology (1982) 110(2):600-6. doi:10.1210/ endo-110-2-600

84. Nielsen JH. Growth and function of the pancreatic beta cell in vitro: effects of glucose, hormones and serum factors on mouse, rat and human pancreatic islets in organ culture. Acta Endocrinol Suppl (Copenh) (1985) 266:1-39.

85. Nielsen JH, Linde S, Welinder BS, Billestrup N, Madsen OD. Growth hormone is a growth factor for the differentiated pancreatic beta-cell. Mol Endocrinol (1989) 3(1):165-73. doi:10.1210/mend-3-1-165
86. Nielsen JH, Møldrup A, Billestrup N, Petersen ED, Allevato G, Stahl M. The role of growth hormone and prolactin in beta cell growth and regeneration. Adv Exp Med Biol (1992) 321:9-17. doi:10.1007/978-1-4615-3448-8_2 discussion 9-20

87. Brelje TC, Scharp DW, Lacy PE, Ogren L, Talamantes F, Robertson M, et al. Effect of homologous placental lactogens, prolactins, and growth hormones on islet B-cell division and insulin secretion in rat, mouse, and human islets: implication for placental lactogen regulation of islet function during pregnancy. Endocrinology (1993) 132(2):879-87. doi:10.1210/endo.132.2.8425500

88. Brelje TC, Sorenson RL. Role of prolactin versus growth hormone on islet B-cell proliferation in vitro: implications for pregnancy. Endocrinology (1991) 128(1):45-57. doi:10.1210/endo-128-1-45

89. Swenne I. Pancreatic beta-cell growth and diabetes mellitus. Diabetologia (1992) 35(3):193-201. doi:10.1007/BF00400917

90. Nielsen JH, Galsgaard ED, Møldrup A, Friedrichsen BN, Billestrup N, Hansen JA, et al. Regulation of beta-cell mass by hormones and growth factors. Diabetes (2001) 50(Suppl 1):S25-9. doi:10.2337/diabetes.50.2007.S25

91. Freemark M, Avril I, Fleenor D, Driscoll P, Petro A, Opara E, et al. Targeted deletion of the PRL receptor: effects on islet development, insulin production, and glucose tolerance. Endocrinology (2002) 143(4):1378-85. doi:10.1210/ endo.143.4.8722

92. Sorenson RL, Brelje TC. Adaptation of islets of Langerhans to pregnancy: betacell growth, enhanced insulin secretion and the role of lactogenic hormones. Horm Metab Res (1997) 29(6):301-7. doi:10.1055/s-2007-979040

93. Tomic S, Chughtai N, Ali S. SOCS-1, -2, -3: selective targets and functions downstream of the prolactin receptor. Mol Cell Endocrinol (1999) 158(12):45-54. doi:10.1016/S0303-7207(99)00180-X

94. Vasavada RC, Garcia-Ocaña A, Zawalich WS, Sorenson RL, Dann P, Syed M, et al. Targeted expression of placental lactogen in the beta cells of transgenic mice results in beta cell proliferation, islet mass augmentation, and hypoglycemia. J Biol Chem (2000) 275(20):15399-406. doi:10.1074/jbc.275.20.15399

95. Buteau J, Foisy S, Rhodes CJ, Carpenter L, Biden TJ, Prentki M. Protein kinase Czeta activation mediates glucagon-like peptide-1-induced pancreatic beta-cell proliferation. Diabetes (2001) 50(10):2237-43. doi:10.2337/ diabetes.50.10.2237

96. Otani K, Kulkarni RN, Baldwin AC, Krutzfeldt J, Ueki K, Stoffel M, et al. Reduced beta-cell mass and altered glucose sensing impair insulin-secretory function in betaIRKO mice. Am J Physiol Endocrinol Metab (2004) 286(1):E41-9. doi:10.1152/ajpendo.00533.2001

97. Okada T, Liew CW, Hu J, Hinault C, Michael MD, Krtzfeldt J, et al. Insulin receptors in beta-cells are critical for islet compensatory growth response to insulin resistance. Proc Natl Acad Sci U S A (2007) 104(21):8977-82. doi:10.1073/pnas.0608703104

Conflict of Interest Statement: The authors declare that the research was conducted in the absence of any commercial or financial relationships that could be construed as a potential conflict of interest.

Copyright $(2016$ Ye and Driver. This is an open-access article distributed under the terms of the Creative Commons Attribution License (CC BY). The use, distribution or reproduction in other forums is permitted, provided the original author(s) or licensor are credited and that the original publication in this journal is cited, in accordance with accepted academic practice. No use, distribution or reproduction is permitted which does not comply with these terms. 